\title{
Sero-prevalence study of bluetongue infection in sheep and goats in selected areas of Ethiopia
}

\author{
Daniel Gizaw ${ }^{1^{*}}$, Demeke Sibhat ${ }^{1}$, Brehan Ayalew $^{1}$ and Mesfin Sehal ${ }^{1}$ \\ ${ }^{1}$ National Animal Health Diagnostic and Investigation Center (NAHDIC), P.O. Box 04, Sebeta, \\ Ethiopia \\ *Corresponding Author: National Animal Health Diagnostic and Investigation Center, P.O. Box \\ 04, Sebeta, Ethiopia, Email:nebiyudan@gmail.com \\ http://dx.doi.org/10.4314/evj.v20i1.8
}

\begin{abstract}
Bluetongue is an infectious, a non-contagious, arthropod borne viral disease of ruminants and has been reported from most of the tropical and subtropical regions of the world. Seroprevalence study was carried from July, 2013 to January, 2015 to understand bluetongue virus infection in selected areas of sheep and goats found in and around small ruminant breed improvement center. A total of 1420 sera samples from sheep and goats were collected and screened for the presence of group specific bluetongue virus antibody using competitive Enzyme-Linked Immuno-Sorbent Assay(c-ELISA) with sensitivity of $100 \%$ and specificity of $99 \%$. The overall seroprevalence of bluetongue virus antibody was $69.01 \%$ and $60.53 \%$ in sheep and goats, respectively. Seroprevalence of bluetongue ranges from $14.5 \%$ (Adami Tulu Research Center) to $91.43 \%$ (Benestemay). Antibody to bluetongue virus was detected from both sheep and goats in all study areas. Result of this study showed that small ruminant dwelling in and around the small ruminant breed improvement centers are exposed to bluetongue virus. In the present study areas there were no observation of clinical cases in any species of animals. This indicates that local breed of animals are resistant to clinical disease of bluetongue infection and or there may be circulation of mild virus strain in the population and so further studies are required to determine the bluetongue serotypes that are circulating in sheep and goats.
\end{abstract}

Keywords: Bluetongue Virus, ELISA, Seroprevalence, Sheep and Goats, Ethiopia 


\section{Introduction}

Bluetongue was first described in the Cape Colony of South Africa after merino sheep were introduced into the region in the late $18^{\text {th }}$ century and was subsequently recognized in other parts of Africa, Europe, the Middle East and Indian subcontinent, Americas, Asia, Australia and several islands in the tropics and subtropics (Howell, 1979). Twenty four (likely 25) serotypes of bluetongue virus (BTV) are recognized globally and the virus has now been isolated on all continents except Antarctica (Hofmann et al., 2008). Bluetongue virus (BTV) is an arthropod borne Orbivirus in the family Reoviridae. There is considerable genetic variability within the serogroup. This arises either by genetic drift of individual gene segments or by reassortment of gene segments when ruminants or the vectors are infected with more than one strain.

The distribution and intensity of infection is determined by the climate, geography and altitude, as these affect the occurrence and activity of the $\mathrm{Cu}$ licoides vectors and the presence of susceptible mammalian hosts. It usually occurred where sheep industries have been established by the introduction of European fine wool and mutton breeds (Davies and Walker, 1974; Howell, 1979; Maclachlan et al., 2009). Native sheep have a high level of innate resistance rendering most infections totally benign. Cattle and goats are involved in maintaining the virus wherever it occurs but disease is seldom seen in any breed. Although bluetongue does not appear to be a major economic constraint to African livestock breeders and it adversely affect the success of livestock improvement projects (Haresnape et al., 1988).

In endemic areas the infection is always present but clinical disease of the indigenous species is unusual. It can occur with new BTV strains and when non indigenous susceptible species are introduced to the area. Infection occurs in a number of animals but significant disease occurs only in sheep. Infection of bluetongue is also seen in cattle but also recorded in elk, white-tailed deer, pronghorn antelope, camels and other wild ruminants. The disease is not contagious and is transmitted biologically by certain species of culicoides (Du Toit, 1944). Bluetongue infection is seasonal because Culicoides life depends on the climate change. Culicoides breed in damp, wet areas including streams, irrigation channels, muddy areas and fecal runoff areas around farms and habitats for them exist on the majority of farm environments. Cattle are the reservoir 
and amplifying host and have a high titer viremia (Sperlova and Zendulkova, 2011).

Cattle appear to be much more attractive to Culicoides spp. and this may enhance the importance of cattle as carriers. Seroprevalence increases with age and probably a reflection of increased duration of exposure. All breeds of sheep are susceptible but to varying degrees. Merinos and British breeds are more susceptible than native African sheep (Davies and Walker, 1974; Howell, 1979; Maclachlan et al., 2009). The objective of the serosurveillance was to determine the seroprevalence of bluetongue virus in goats and sheep in and around selected sheep and goat breed improvement centers in Ethiopia.

\section{Materials and Methods}

\section{Study areas}

Melka Warer Agricultural Research Center in Afar Regional State keeps local and exotic goat breeds. Adami Tulu Agricultural Research Center of Oromiya Regional State keeps local and exotic goat breeds, Areka and Jinka Agricultural Research Centers in Southern Nations Nationalities and Peoples Regional State (SNNPRS) which keep local and exotic sheep and goat breeds, respectively, Fafan Agricultural Research Center in Somali Regional State also keeps sheep and goats. These sheep and goats are intended for breed improvement of the local sheep and goats, respectively. Farmers owning sheep and goat in three to four kebeles adjacent to the breeding centers were also included in the survey.

\section{Study population}

The populations of interest were those animals which were kept by breed improvement centers for small ruminant in different parts of the country. The breed improvement center kept both local and cross breed sheep (Ovis iris) and goats (Capra hircus). Local and cross breeds of sheep and goats that were kept tin surrounding kebels were also included.

\section{Study design}

This study was carried out from January, 2013 to January, 2015. The animals were sampled using systematic random sampling technique whereas the first 
animals selected randomly from the flock and then $\mathrm{n}^{\text {th }}$ number of animals was sampled until the samples for that flock was reached. Age was determined by observation of the erupted permanent incisors (De launta and Habel, 1986). Animals' less than one year were considered as young while those greater than or equal to one years were considered as adult.

\section{Sampling procedure}

About 5 to $7 \mathrm{ml}$ of blood were collected from jugular vein in plain vacationer tube from each animal and put in slightly inclined position in order to separate serum from blood. Then sera were extracted and labeled and stored immediately at $4^{\circ} \mathrm{C}$ until they arrived at the laboratory. Sera were stored at minus $20^{\circ} \mathrm{C}$ until testing. Epidemiological data related to clinical syndrome of bluetongue were also collected using questionnaire format prepared for this purpose.

\section{Laboratory test}

Sera samples were examined for the presence of BTV group specific antibodies using a competitive enzyme-linked immunosorbent assay (c-ELISA) which was manufactured by (VMRD INC, P.O. box 502, Pullman WA 99163 USA). It has been demonstrated to detect all 24 known serotypes of bluetongue virus (BTV) and not to detect antibody to serotypes 1 or 2 of epizootic hemorrhagic disease virus (EHDV). It has sensitivity and specificity of $100 \%$ and $99 \%$, respectively. The test protocol briefly described as $25 \mu \mathrm{l}$ of control and test sera were dispensed according to the test plate lay out and incubate at $21-25^{\circ} \mathrm{C}$ at room temperature for 15 minutes. After 15 minute $25 \mu l$ peroxidase conjugate was added and incubate for additional 15 minute at $21-25^{\circ} \mathrm{C}$ at room temperature. The plate was washed three times and then $50 \mu \mathrm{l}$ substrate solution was dispensed to each well. The plate was incubated at $21-25^{\circ} \mathrm{C}$ at room temperature for 10 minute. The reaction was stopped by adding $50 \mu \mathrm{l}$ of stop solution and the plate was read at $650 \mathrm{~nm}$ optical density. Test sera that were turned optical density greater or equal to $50 \%$ mean of negative controls were considered negative while those less than $50 \%$ were considered positive. 


\section{Data management and analysis}

Data collected were entered in to Microsoft Excel spreadsheet and descriptive statistic was done using SPSS 18.0 (SPSS Inc., Chicago, IL, USA). Chi-square test and Fisher's exact tests were applied to analyze the association between seroprevalence status among age, sex, breed and specie values less than or equal to 0.05 were considered to be significant.

\section{Results}

A total of 1420 goats and sheep sera samples were tested from different part of the country. The overall seroprevalence was 60.53 and $69.1 \%$ in caprine and ovine, respectively. Seroprevalence in the centers and surrounding kebeles ranges from $23.65 \%$ in Adami Tulu to $91.43 \%$ in Benetsemay (Table 1). Seroprevalence of the bluetongue in sheep and goats in the centers was $64.69 \%$ (621/960) while in the surrounding kebeles it was $66.3 \%(305 / 460)$. There is no significant variation in seroprevalence of the bluetongue between centers and surrounding kebeles $(\mathrm{p}=0.6)$.

Table 1: Seroprevalence of bluetongue in selected areas of Ethiopia

\begin{tabular}{lccccc}
\hline Centers or site & $\begin{array}{c}\text { No. of } \\
\text { tested }\end{array}$ & No. positive & $\begin{array}{c}\text { Percentage } \\
\text { Positive }\end{array}$ & 95 \% confidence interval \\
\hline Adami tulu & 241 & 57 & 23.65 & 15.09 & 32.21 \\
Ambara & 354 & 266 & 75.14 & 70.40 & 79.88 \\
Areka & 144 & 70 & 48.61 & 42.68 & 54.54 \\
Arsi Negelle & 50 & 34 & 68.00 & 63.02 & 72.98 \\
Bene tsemay & 70 & 64 & 91.43 & 87.13 & 95.73 \\
Doyo Gena & 76 & 52 & 68.42 & 63.44 & 73.40 \\
G/Mekeda & 30 & 24 & 80.00 & 75.41 & 84.59 \\
Fafan & 280 & 205 & 73.21 & 68.40 & 78.02 \\
Jinka & 175 & 154 & 88.00 & 83.62 & 92.38 \\
Total & 1420 & 926 & 65.21 & 60.05 & 70.35 \\
\hline
\end{tabular}

There were significant variation in seroprevalence of bluetongue among age, sex and species but there were no variation in seroprevalence of bluetongue in local and cross breed $(\mathrm{p}<0.05)$ (Table 2$)$. 
Table 2: Seroprevalence of the bluetongue in different age, sex and breed groups

\begin{tabular}{|c|c|c|c|c|c|c|}
\hline Category & $\begin{array}{c}\text { No of } \\
\text { sample } \\
\text { tested }\end{array}$ & $\begin{array}{c}\text { No of } \\
\text { sample } \\
\text { positive }\end{array}$ & $\begin{array}{l}\text { Percentage } \\
\text { Positivity }\end{array}$ & \multicolumn{2}{|c|}{$\begin{array}{c}95 \% \\
\text { confidence } \\
\text { interval }\end{array}$} & $\begin{array}{c}\text { Pearson Chi- } \\
\text { Square }\end{array}$ \\
\hline \multicolumn{7}{|l|}{ Age } \\
\hline Adult ( $\geq 1$ year ) & & 955 & 643 & 67.33 & 66.23 & $\mathrm{P}$-value 0.018 \\
\hline Young(<1year ) & & 465 & 283 & 60.86 & 59.70 & \\
\hline \multicolumn{7}{|l|}{ Sex } \\
\hline Female & Female & 1151 & 784 & 68.11 & 65.54 & $\mathrm{P}$-value 0.000 \\
\hline Male & Male & 269 & 142 & 52.79 & 49.85 & \\
\hline \multicolumn{7}{|l|}{ Breed } \\
\hline Cross & 767 & 455 & 59.32 & 57.01 & 61.63 & $\mathrm{P}$-value 0.406 \\
\hline Local & 653 & 471 & 72.13 & 70.04 & 74.22 & \\
\hline \multicolumn{7}{|l|}{ Species } \\
\hline Caprine & 636 & 385 & 60.53 & 59.01 & 62.05 & $\mathrm{P}$-value 0.001 \\
\hline Ovine & 784 & 541 & 69.01 & 67.60 & 70.42 & \\
\hline Total & 1420 & 926 & 65.21 & 60.05 & 70.35 & \\
\hline
\end{tabular}

Seroprevalence in kebeles or sites ranges from $14.5 \%$ in Adami Tulu Agricultural Research Center to $91.43 \%$ at Oleka Kibra in Benetsemay wereda (Table $3)$. 
Table 3: Seroprevalence of bluetongue in selected kebele and farms in agricultural research centers

\begin{tabular}{|c|c|c|c|c|c|}
\hline Farm /Kebele & $\begin{array}{l}\text { No. of } \\
\text { tested }\end{array}$ & $\begin{array}{l}\text { No. of } \\
\text { positive }\end{array}$ & $\begin{array}{l}\text { Percentage } \\
\text { positivity }\end{array}$ & \multicolumn{2}{|c|}{$\begin{array}{c}95 \% \text { confidence } \\
\text { interval }\end{array}$} \\
\hline Rafu Aregesa & 50 & 34 & 68.0 & 62.8 & 73.2 \\
\hline $\begin{array}{l}\text { Areka Agricultural } \\
\text { Research Center }\end{array}$ & 144 & 70 & 48.6 & 42.4 & 54.8 \\
\hline $\begin{array}{l}\text { Adami Tulu Agricultural } \\
\text { Research Center }\end{array}$ & 145 & 21 & 14.5 & 3.0 & 26.0 \\
\hline Awra Ara & 76 & 52 & 68.4 & 63.2 & 73.6 \\
\hline $\begin{array}{l}\text { Fafan Agricultural } \\
\text { Research Center }\end{array}$ & 142 & 110 & 77.5 & 72.6 & 82.4 \\
\hline Golatobi & 43 & 18 & 41.9 & 35.2 & 48.6 \\
\hline Halla Hago & 43 & 25 & 58.1 & 52.4 & 63.8 \\
\hline $\begin{array}{l}\text { Jinka Agricultural } \\
\text { Research Center }\end{array}$ & 175 & 154 & 88.0 & 83.4 & 92.6 \\
\hline Kubajane & 53 & 42 & 79.2 & 74.4 & 84.0 \\
\hline Kudhac & 42 & 28 & 66.7 & 61.4 & 72.0 \\
\hline Marta & 30 & 24 & 80.0 & 75.2 & 84.8 \\
\hline Oleka Kibra & 70 & 64 & 91.4 & 86.9 & 95.9 \\
\hline $\begin{array}{l}\text { Melka Warer Agricultural } \\
\text { Research Center }\end{array}$ & 354 & 266 & 75.1 & 70.1 & 80.1 \\
\hline Weyso konchoso & 53 & 18 & 34.0 & 26.6 & 41.4 \\
\hline Total & 1420 & 926 & 65.2 & 60.05 & 70.35 \\
\hline
\end{tabular}

\section{Discussion}

The detection of antibodies against bluetongue virus in different part of the country in our studies indicates that bluetongue virus infection is endemic among small ruminants. Serological tests indicate that bluetongue virus is circulating in all studied areas. Relatively higher seroprevalence of bluetongue was reported from different areas of the world. The seroprevalnce of 60.53 and $69.1 \%$ in caprine and ovine, respectively in our study was lower than that study of Mulabbi et al. (2013) reported 90\% seroprevalence in goats in Uganda. There were similar studies and findings by Yousef et al. (2012) who reported seroprevalence of $54.1 \%$ and $53.3 \%$ in sheep and goats, respectively, in Saudi Arabia. Different studies show that bluetongue virus infection widely distributed and reported from many countries in the world including Turkey $29.5 \%$ by 
Gur (2008), India $45.7 \%$ by Sreenivasulu et al. (2004), Pakistan $48.8 \%$ Akhtar et al. (1997) and in Iran $89.2 \%$ by Vahid and Mahin (2013).

There was higher seroprevalence of bluetongue in ovine (69.1\%) than in caprine (60.53\%) in our studies. Similarly higher seroprevalence of bluetongue in sheep (17.5\%) than goat (14.7\%) was reported by Mahmoud and Khafagi (2014) in Egypt. In contrast to our findings higher seroprevalence in goat $67.7 \%$ was reported in Iran Ali et al. (2014). This may be due to difference in reaction of ovine and caprine to vector of bluetongue virus. In this study seroprevalence of $72.13 \%$ in local breed and $59.32 \%$ in cross breed was reported however, there was no statistical variation in seroprevalence of bluetongue in local and cross breed $(\mathrm{p}<0.05)$. This may be due to equal exposure of both cross and local breed to bluetongue vectors since they managed similarly.

There was significant variation of seroprevalence among age, sex and species $(p<0.05)$. Evidence of rising antibody seroprevalence with age suggests that there were a series of years in which a widespread of infection with bluetongue was occurred Hawel, 1079 and Mohammadi et al. (2012). However, this evidence could result either from the continuous presence of the virus or annual re-infections of an external source.

The seroprevalence of bluetongue has been detected among sheep and goats in different areas of Ethiopia indicating serological evidence of exposure to infection to be widely distributed all over the country. Antibody to bluetongue virus was detected in low land (Benestemay) to high land (Doyo Gena). The result of competitive ELISA indicates that bluetongue is prevalent in all studied areas. A clinical case of bluetongue was not observed among animals sampled during clinical examination and so far no cases have been reported in Ethiopia. The absence of clinical disease suggests that indigenous breed of sheep and goats have a high degree of innate immunity Haresnape et al. (1988). This phenomenon could be changed if more virulent strains are able to gain entry or if host resistance is to be lowered by cross-breeding. As blood level of the exotic breed increased either through breed improvement or introduction of susceptible population bluetongue could be assumed to be one of the threats to livestock development. 


\section{Conclusion}

This study indicates that local breed of animals are resistant to clinical disease of bluetongue infection and or there may be circulation of mild virus strain in the population and so further studies are required to determine the bluetongue serotypes that are circulating in sheep and goats in Ethiopia in order to devices control strategy.

\section{Acknowledgment}

The authors would like to acknowledge small ruminant owners and agricultural research centers in the study areas for allowing the investigators to get samples from their animals and their participation in handling of animals. We would also like to acknowledge the Regional Veterinary Laboratories, Animal Health Professionals and Development Agents for their cooperation and participation during the study.

\section{References}

Akhtar, S., Djallem, N., Shad, G. and Thiemo, O., 1997. Bluetongue virus seropositivity in sheep flocks in North West Frontier Province, Pakistan. Prev. Vet. Med., 29, 293-8.

Asghar, A., Mozaffari, M. and Sabahi, S., 2014. High seroprevalence of bluetongue virus antibodies in goats in southeast Iran. Asian Pac. J. Trop. Biomed., 4(1), 275-S278.

Davies, F. G. and Walker, A. R., 1974. The distribution in Kenya of bluetongue virus and antibody, and the Culicoides vector. J. Hyg., 72, 265-272.

Du-Toit, R.M., 1944. The transmission of bluetongue and horse sickness by Culicoides. J. Vet. Anim. Ind., 19, 7-16.

Ghanem, Y.M., Fayed, A.A., Saad, A.A. and Abdelkader, A.H., 2009. Serological survey on bluetongue virus infection in camels at two camel-rearing regions of Somaliland. Assiut. Vet. Med. J., 56, 77-87.

Gur, S., 2008. A serologic investigation of bluetongue virus (BTV) in cattle, sheep and gazella Subgutturosa subgutturosa in southeastern Turkey. Trop. Anim. Hlth. Prod., 40, 217-21.

Haresnape, J.M., Taylor, W.P. and Lunggu, S.A.M., 1988. The epidemiology of bluetongue in Malawi. Epidem. Infect., 100, 493-499.

Ethiop. Vet. J., 2016, 20 (1), 105-114 
Hofmann, M.A., Renzullo, S., Mader, M., Chaignat, V., Worwa, G. and Thuer, B., 2008. Genetic characterization of Toggenburg Orbivirus, a new bluetongue virus from goats, Switzerland. Emerg. Infect. Dis., 14, 1855-1861.

Howell, P.G., 1979. The epidemiology of bluetongue in South Africa. In: Proceedings of the $2^{\text {nd }}$ Symposium on Arbovirus Research in Australia (ed. T. D. St. George and E. L. French), pp. 117-123.

Maclachlan, N.J., Drew, C.P., Darpel, K.E. and Worwa, G., 2009. The pathology and pathogenesis of bluetongue. J .Comp. Pathol., 141,1-16.

Mahmoud, M.A. and Khafagi, M.H.,2014. Seroprevalence of bluetongue in sheep and goats in Egypt. Vet. World., 7, 205-208.

Mohammadi, A., Tanzifi, P. and Nemati, Y., 2012. Seroepidemiology of bluetongue disease and risk factors in small ruminants of Shiraz suburb, Fars province, Iran. Trop. Biomed., 29(4), 632-637.

Sperlova, A. and Zendulkova, D., 2011. A review article of bluetongue: Vet. Med., 56 (9), 430-452.

Sreenivasulu, D., Subba Rao, M.V., Reddy, Y.N. and Gard, G.P., 2004. Overview of bluetongue disease, viruses, vectors, surveillance and unique features the Indian subcontinent and adjacent regions. Vet. Itali., 40, 73-77.

Najarnezhad, V. and Rajae, M., 2013. Seroepidemiology of bluetongue disease in small ruminants of northeast of Iran. Asian Pac. J. Trop. Biomed., 13, 60102-1.

Yousef, M.R., Al-Eesa, A.A. and Al-Blowi, M.H., 2012. High seroprevalence of bluetongue virus antibodies in sheep, goats, cattle and camel in different districts of Saudi Arabia, Vet. World., 5(7), 389-393. 